\title{
30 Years of Cellular and Health Populations (There is a Realization, Forecast of Dangerous, Recommendations)
}

\section{Grigoriev $\mathrm{Yu}^{*}$}

Russian National Committee on Non-Ionizing Radiation Protection, Moscow, Russia

\section{Short Communication}

At present, man-made electromagnetic pollution of the environment. It has increased by exposure cellular base stations.

The greatest danger for all populations is cell phones (CPh). It is an open source of electromagnetic radiation that has no protection available for all groups of the population do not have any restrictions and when there is local EMF irradiation exposure of the brain of the user.

Domestic and foreign results allow us to conclude about the possible adverse effects of RF EMF on health by CPh. EMF RF exposure of low level can cause infringements of function of a brain $[1,2]$ (including convulsive syndrome $[3,4]$. We agree with the decision of the International Agency for Research on Cancer (IARC), WHO allocation $\mathrm{EMI} \mathrm{CPh}$ in group $2 \mathrm{~B}$ as a promoter of brain cancer and Hardell's results [5].

Children have to stand in a special risk group, because using $\mathrm{CPh}$ brain child doubles as the absorbed dose and the irradiated volume of the brain. The brain of children is under development. The potential risk to children's health is very high. It's very important WHO publication:

"CHILDREN ARE DIFFERENT FROM ADULTS. Children have a unique vulnerability. As they grow and develop, there are "windows of susceptibility": periods when their organs and systems maybe particularly sensitive to the effect of certain environmental threats". WHO, Backgrounder N.

Modern children will use mobile phones for longer periods than adults of the present generation because they started to use mobile phones at an early age and will continue use them when they became adults.

We have our own experience of long-term observation of children who are CPh users. In 2006, we began long-term physiological studies of children of primary school who are MP users [6].

It should be noted that in these studies, apart from the main group in which children use $\mathrm{CPh}$, was formed a control group whose children did not have MPh and did not use them. The study was performed at the Lyceum, Moscow.

Complex diagnostics of neurodynamic characteristics of children included psychophysiological indicators, assessment of neuropsychological status and level of language development, as well as analysis of anamnestic and biographical data.

The following functional changes (preliminary results) in $\mathrm{CPh}$ users have obtained:

- $\quad$ Fatigue (39.7\%)

- $\quad$ Reduced ability to work in school and at home (50.7\%)

- Decrease the stability of voluntary attention (production-14.3\%, accuracy 19.4\%)

- Weakening of semantic memory (accuracy-19.4\%, increasing the time-30.1\%)-change the speed auditory-motor reaction $(55.5 \%)$

- Violation of phonemic perception (all children-users)

- Similar results were obtained in India for the study of audition, but for the adult users of the MPh [7].

RNCNIRP (April, 2008) made already the third decision on possible danger EMF RF for children "CHILDREN AND MOBILE PHONES: THE HEALTH OF THE FOLLOWING GENERATIONS IS IN DANGER". In this decision it has been paid attention of scientific community, Ministry of Health, that for the first time in history, we face a situation when most children and teenagers in the world are continuously exposed to the potentially adverse influence of the electromagnetic fields (EMF) from mobile phones. Children and teenagers became the target group for the marketing the mobile communications.

The WHO considers the protection of the children's health from possible negative influence of the EMF of the mobile phones as a highest priority task. This problem has also been confirmed by the Scientific Committee of the European Commission. The potential risk for the children's health is very high [8].

The existing standards have become outdated, do not correspond of real conditions and require reconsideration. In 2009 year the European parliament has required reconsideration of the standards: item 22 "Standards/limits of influence of electromagnetic fields (EMF), which are intended for the population, have become outdated".

In our opinion, there is enough evidence to inform the public about the health hazards of $\mathrm{CPh}$ users and introduce the concept of "voluntary risk", the principle of self-selection of the type of communication by the population with the maximum reduction of electromagnetic load on the user's brain $\mathrm{CPh}$.

\section{References}

1. Grigoriev YuG, Grigoriev OA (2014) Cellular communication and health Electromagnetic environment. Radiobiology and hygiene problems. Forecast of danger. Gig Sanit 93: 117-118

2. Repachoy M, Grigoriev Y, Bushmann J, Pioli C (2012) Scientific basis for the Soviet and Russian radiofrequency standards for the general public. Bioelectromagnetics 33: 623-633.

*Corresponding author: Yu G, President, Russian National Committee on NonIonizing Radiation Protection, 46, Zhivopisnaya str., 123182, Moscow, Russia, Tel: +7 (499) 1909660; E-mail: profgrig@gmail.com

Received June 23, 2015; Accepted October 28, 2015; Published October 30 , 2015

Citation: Yu G (2015) 30 Years of Cellular and Health Populations (There is a Realization, Forecast of Dangerous, Recommendations). Review Pub Administration Manag 3: 173. doi:10.4172/2315-7844.1000173

Copyright: (c) $2015 \mathrm{Yu}$ G. This is an open-access article distributed under the terms of the Creative Commons Attribution License, which permits unrestricted use, distribution, and reproduction in any medium, provided the original author and source are credited. 
Citation: Yu G (2015) 30 Years of Cellular and Health Populations (There is a Realization, Forecast of Dangerous, Recommendations). Review Pub Administration Manag 3: 173. doi:10.4172/2315-7844.1000173

Page 2 of 2

3. Grigoriev Y, Sidorenko A (2011) Nonthermal Electromagnetic Fields and Estimation of the Probable Development of the Convulsive Syndrome. Biophysics 56: 351-357.

4. Grigoriev YG, Grigoriev OA, Ivanov AA, Lyaginskaya AM, Merkulov AV, et al (2010) Confirmation studies of Soviet research on immunological effects of microwaves: Russian immunology results. Bioelectromagnetics 31: 589-602.

5. Hardell L, Carlberg M (2009) Mobile phones, cordless phones and the risk for brain tumours. Int J Oncol 35: 5-17
6. Grigoriev YuG, Khorseva MI (2014) Mobile communications and children health. Assesment of hazard of mobile phone use by children and teenagers. Recommendations to children and parents. 229

7. Panda NK, Jain R, Bakshi J, Munjal S (2010) Audiologic disturbances in longterm mobile phone users. J Otolaryngol Head Neck Surg 39: 5-11.

8. Markov M, Grigoriev $Y$ (2015) Protect children from EMF. Electromagn Bio Med 34: 251-256. 